\title{
THE PARETO SALES NETWORK ASSET: A NETWORKED POWER PERSPECTIVE
}

\author{
Augusty Tae FERDINAND ${ }^{1}$, Maklon Felipus KILLA ${ }^{2}$ \\ ${ }^{1}$ Management Department, Diponegoro University, Indonesia \\ ${ }^{2}$ Management Department, Wira Wacana Christian University, Indonesia \\ E-mails: augusty@live.undip.ac.id (correspondingauthor); maklonk@yahoo.com
}

Received 10 April 2018; accepted 11 May 2018

\begin{abstract}
The purpose of this research is to develop a conceptual model dealing the relationship between EO and sales growth performance by proposing the Pareto sales network asset as a reliable bridge for mediating EO and sales growth performance in SMEs in Indonesia. Lending the network theory and the Pareto concept, we propose a concept on The Pareto sales network asset as a strategic asset for enhancing sales growth performance. The main finding of this study is that an entrepreneurial oriented firm who success in accessing the Pareto sales network which by nature is outside of the firm will get the networked power. Having, maintaining and using the networked power getting from a Pareto sales network asset will be a key asset for enhancing sales growth performance. The acceptance of the hypotheses on the role of the Pareto sales network asset demonstrated the importance of this strategic asset for SMEs in enhancing performance.
\end{abstract}

Keywords: entrepreneurial orientation, networked power, Pareto sales network asset, marketing support advantage, sales growth performance, Indonesia.

JEL Classification: M13, M310, D83, L14.

\section{Introduction}

The concept of Entrepreneurial Orientation (EO) is extremely well known in a long history of business studies within the field of strategic management and entrepreneurship studies (Madsen 2007, Tang et al. 2007). Research on EO deals with the strategic role played by entrepreneurs, how entrepreneurs act, react, pro-act, and win in the market. An entrepreneur is associated with someone who has a particular capability to create a series of distinct newness and breakthrough in: business ideas development by knowledge process (Li et al. 2009, Shane et al. 2003), business orientation (Home 2011, Morris et al. 2002, Ramachandran and Ramnarayan 1993, York and Venkataraman 2010), business-process (Bayhan et al. 2013), and product or service (Akgün et al. 2014, Avlonitis and Salavou 2007) as a strategic key to his/her success uniquely or innovatively. These individuals possess entrepreneurial skills and are familiar with several personal specific attributes such as innovativeness, risk-taking, and pro-activeness (Lumpkin and Dess 2001, Pearce II et al. 2010).

These characteristics lead entrepreneurs or entrepreneurial firms to act and react in a specific manner of social and business activity in the marketplace; they are intrinsically motivated to enhance their competitive advantage. This basis holds potential to increase the company performance, i.e., a person with an EO will have the potential to achieve good business performance, as proven by many studies in these decades (Lumpkin and Dess 2001, Merlo and Auh 2009, Semrau et al. 2016, Wiklund 1999) However, study of another scholars indicated there is no impact of EO to performance (Avlonitis and Salavou 2007, Baker and Sinkula 2009, Davis et al. 2010, Frank et al. 2010, Hughes and Morgan 2007, Madsen 2007, Soininen et al. 2012, Walter et al. 2006). Those findings indicated clearly a research gap that study on the influence of EO to performance to some extent is still inconclusive. In another side,

\footnotetext{
Copyright (c) 2018 The Authors. Published by VGTU Press.

This is an Open Access article distributed under the terms of the Creative Commons Attribution License (http://creativecommons.org/licenses/by/4.0/), which permits unrestricted use, distribution, and reproduction in any medium, provided the original author and source are credited..
} 
if $\mathrm{EO}$ is recognized as company strategic input resources as shown in several studies such as in Wolff, Pett, and Ring (2015) and Morgan, Anokhin, and Wincent (2016) who pinpointed EO provides the firm with partial capabilities of enhancing the success or performance as an output, it is still not clear what process should be taken into a strategic action for transforming the input-EO for effectively enhancing performance. We address this issue as an effort to get a more understanding of how to manage $\mathrm{EO}$ to be a driver for enhancing company performance in terms of sales growth performance, as has been endorsed by Rauch, Wiklund, Lumpkin, and Frese (2009), who claimed that even though EO is a good predictor of company performance, it is still necessary to analyze the potential of any mediator variable that explains the process for the relationship between the two.

The current study is addressing the process for relating EO to a performance by adopting the concept of networking and assumes that a network asset, especially marketing or sales network is essential for enhancing performance. Why does entrepreneur need a network? The answer should be rooted in the conception of networked power (Castells 2011) in a sense if a network tie between entrepreneurs and outside person or institution of distribution channel occur, it might be expected there will be a powerful value co-creation capability for sustaining the performance. Network concept is chosen for its relevance to the basic argument that an entrepreneurial style in doing business in SMEs is not sufficient for value creation on its own (Naudé et al. 2014) occupying certain complement resources such as distribution network is necessary for a better process in value creation and value offering. Numerous studies have already been conducted to analyze the effect of networking in improving marketing performance within an entrepreneurial setting. Walter et al. (2006) explained the growth and sustainability of a firm are dependent on its ability to develop, sustain, and enlarge its network, demonstrating the importance of networking in conducting business. Our study adopts the concept of networking and constructs the Pareto sales network asset for bridging the relationship between EO and Sales growth performance. The objective of this research is to develop a conceptual model for fulfilling the research gap on EO to increase company performance regarding sales growth performance through the utilization of Pareto sales network asset and marketing support advantage.

\section{Literature review and hypothesis development}

\subsection{Entrepreneurial Orientation (EO)}

Study on EO has attracted researchers for decades (AlDhaafri et al. 2016, Covin and Slevin 1989, Lumpkin and Dess 1996, Miller and Friesen 1982, Walter et al. 2006,
Wiklund 1999). The importance of EO could be seen in at least two strategic angles. Firstly, research on EO uncovers our understanding on the role of EO as a managerial philosophy of doing business and crafting the strategy innovatively, progressively equipped with an ability to take and manage risk followed by any decision. Firm or person that is always seeking new ways and breakthrough will innovate boldly and regularly while taking considerable risk in their product-market strategy (Miller and Friesen 1982). They will motivate and direct the organizational assets to be a capability characterized by innovativeness, pro-activeness, and risk-taking (Covin and Slevin 1989). Secondly, EO is conceptualized as a behavior in the business process. In this sense, EO refers to the propensities, processes, and behaviors that lead to entry into new or established markets with new or existing goods or services (Lumpkin and Dess 1996, Walter et al. 2006), therefore EO is actualized as a strategy practices that guiding a business process which transplanting spirit of entrepreneurship into managerial action such appeared in the study on Al-Dhaafri and AlSwidi (2016).

The current study adopts the concept of the EO as a strategy behavior that transforming EO as an entrepreneurial action taken by an entrepreneur or entrepreneurial company in the form of innovative strategy, a proactive initiative in strategy maneuvering, and ability to manage risk in strategy decision (Covin and Slevin 1989). An innovative strategy indicates firm's ability to preemptively creating new ways of doing business competitively as argued by Hughes and Morgan (2007) that innovativeness is one of the dominant characteristics of entrepreneurial oriented firms. The innovative company has an ability to create new room for safely entering a competitive market, create new series of product and services that might be more attractive to the market, create a new way of thinking in servicing market and provide a sound basis for maneuvering in the competitive market. The entrepreneurial oriented firm is proactive in strategy, not merely reactive. As proven by previous studies, the entrepreneurial oriented company leads strategy to be pro-actively anticipating new opportunities created by market mechanisms and managing risk proportionately for creating profit (Lumpkin and Dess 1996, Miller 1983, Wiklund 1999). Referring to the research findings of Lumpkin and Dess (1996), we assume that entrepreneurial firms will be weaponing themselves with a certain level of competitive aggressiveness and a tendency to act independently and autonomously in the marketplace. Entrepreneurs or entrepreneurial company will always create ways to minimize risk and create alternative ways to strengthen their business platforms through formal and informal networking. Their pre-emptive initiative and decision to make a breakthrough gain success in the marketplace, the ability to manage risk proportionately in any business decision they make is seen as advantageous for networking by their stakeholders. 


\subsection{Pareto sales network asset}

An inspiring study on networking is conducted by Engel, Kaandorp, and Elfring (2017) argue on the conceptualization of entrepreneurial networking, networking is an entrepreneurial action done by an entrepreneur and or an entrepreneurial firm. An entrepreneurial SME is an outward-looking oriented business unit that is proactively exploring opportunities and managing relationship for increasing business program effectiveness. To do so, as argued by Naudé et al. (2014) firm will exploit its capability for building, maintaining and using relationship with institutions outside the company for building a strategic cornerstone in sustaining its business performance. A rationale for building a strong root for access to the marketplace is building a relational tie with a prospective sales network that has a specific capability, named a networked power (Castells 2011). Networked power is power cultivated in a network that has the potential for value co-creation in a business sense. Networking with a type of big impact partners in the channel of distribution is a key determinant for spreading the products and services to customers and end-users. This big impact sales network is proposed in this study as the Pareto sales network asset.

Study on Pareto concept has been done for decades empirically and theoretically in various aspect of business life such as appeared in sales management. Pareto principle focuses on "the vital view" at the cost of "the trivial many" is an accepted management principle (Craft and Leake 2002). The essence of Pareto concept demonstrated a situation in our real life that a certain few strategic factors-known as $20 \%$ strategic elements accounted for almost $80 \%$ of performance, while the remain $80 \%$ factors accounted for only around $20 \%$ of the performance (Sanders 1987).

The application of Pareto concept in marketing strategy especially in the channel of distributional alignment could be understood in several ways. First, the Pareto concept is relevant on the efficiency of market coverage in a sense that company which is working with large size channel of distribution will be more efficient in covering a bigger area of consumer engagement. Second, working with a large size potential channel of distribution will energize the strategic readiness of company in term of improving the performance of relationship of manufacturer and channel of distribution member. By providing quick response management in supply system such as appeared in the study of Iyer and Bergen (1997) that quick response in the manufacturerretailer channel will be profiting channel member, known as a Pareto Improvement. This large size channel of distribution member is named as a Pareto sales network asset. This strategic asset will leverage potential for increasing mutual benefit of company and member of the distribution channel. In the line of this mutual benefit as appeared in the study of Anderson (2002) that marketers will usually treat their customers as a strategic partner for mutually benefitting the sales outcome in term of sales volume, sales growth, sales profit is known as Pareto efficiency. The role of the salesperson is to identify his or her customer's need in serving the end-user consumer and maintain a relationship with customers to achieve an optimum return. Working with big size customer is one an example of the effort to maximize return as a Pareto Efficiency. Therefore, customer asset, especially Pareto customer is recognized as a strategic asset for increasing performance. Third, Working with a kind of Pareto type of member of a channel of distribution will enhance the benefit of a scale of economics as studied by Fabella (2000), demonstrated the larger the scale of economies of business activities, the greater the Pareto efficiency achieved. Moreover, Craft and Leake (2002) explained "all organizations face decision for prioritizing resources to yield the greatest value to the organization," as network member is company outside-in strategic asset, then working with high impact sales network is a priority for sustaining performance. Therefore, we propose Pareto sales network asset as a high impactnetwork or a group of strategic customers that dominantly contribute to company's sales performance because of its ownership of loyal customer, high sales turnover customer, and large network customer. Therefore, the following hypothesis is proposed.

H1: Entrepreneurial orientation positively influences Pareto sales network asset.

\subsection{Pareto sales network asset as a driver for sales growth performance}

SMEs are working with a few employees in the vital functions of business focusing on product development and sales activities doing all marketing functions to enhance performance. In accordance with the resource advantage theory, marketing performance is measured in a multidimensional measure such as: customer perception, customer behavior, sales response, market share (Morgan et al. 2002), sales growth and market growth (Deutscher et al. 2016, Rust et al. 2004), sales, satisfaction, retention, market share (Morgan 2012), average market share growth, average sales volume growth, average sales-in dollars growth (Green et al. 2012).

The current study is using several measures to indicate sales growth performance as an achievement produced by a firm in term of sales growth (Green et al. 2012, Kantur 2016). Another measure is customer growth as a rate of increasing customer as a result of advantages, through the age of the company (Best 2009, Liao et al. 2016). Sales growth performance is also measured by bigger market coverage such as market share, the bigger market segment as a result of a new product offered into the market (Bental and Spiegel 1995, Wang et al. 2015). 
Our study proposes a strategic bridge for enhancing sales growth performance by having the Pareto sales network asset. The strategy for managing a customer portfolio is detailed in a study by Homburg, Steiner, and Totzek (2009), which reveals several lessons, e.g., a company should prioritize its customer segment to enhance its sales performance; customer equity will be strengthened through the potential of a target market. We define the Pareto sales network asset as a group of high impact-strategic customers characterized by bigger business size, wider consumer network, and loyalty to the company. Working with this type of customer group is perceived as working with a key contributor to success. Therefore, the following hypothesis was proposed:

H2: Pareto sales network asset positively influences sales growth performance.

$\mathrm{EO}$ as an entrepreneurial style in doing business. If it is seen as a business process, then EO is a strategic input which entering a process. EO itself is not sufficient for value creation as argued by Naudé et al. (2014), therefore it is necessary for searching complement resources that enabling a better process in value creation and value offering. Adopting the networked power of (Castells 2011) into the business practices, we argue that to enhance performance EO should be managed to engage to certain external entities that have the potential for creating a firm-specific networked power. In the sales management point of view, networking to the channel of distribution is one of the best ways for channeling product to end-users. To do so, building, maintaining and using a Pareto sales network asset should be considered as an appropriate mediator for the relationship between $\mathrm{EO}$ and sales growth performance. Therefore, the following mediation hypothesis is proposed.

H3. The relationship between $E O$ and sales growth performance is mediated by the Pareto sales network asset.

\subsection{Entrepreneurial orientation, Pareto sales network asset, and Marketing support advantage}

If the Pareto sales network asset in important for an entrepreneurial oriented firm, effort to build and maintain a network is a key for sustaining the networked power with a certain co-value creation capability (Naudé et al. 2014). A proactive and innovative entrepreneurial orientated firm will build and maintain its networking by providing all possibilities for harvesting from the network, therefore providing marketing support to the networked distribution channel is seen as the way in maintaining the quality of the Pareto sales network asset.

A continuum practice in marketing and sales management is adopting, promoting and harvesting through the strategic role played by channel distribution system in the marketplace. Manufacturer, especially who work in a small business is depending on distribution channel to spread the product and maintain the sustainability of sales performance. Our literature study indicated the existence of marketing supports offered by companies such as in facilitating product channeling effectiveness to end-user in many ways. The type of supports are product support; sales support, promotion support (Betancourt et al. 2016, Emslie and Bent 2007, Karray 2015, Lee et al. 2011). Manufacturer' support to the channel of distribution is coming through appropriateness of product-oriented approach in the marketplace (Emslie and Bent 2007). Another type of customer support is through personal bonding activities such personal customer contact, knowledge embeddedness in the relationship (Raassens et al. 2014) that having a direct impact to qualify any relationship.

Company's support to sales network may be developed in several ways such as: firstly, providing a relevant product-oriented strategy regarding maintaining a healthy level of distribution services, i.e. assurance of product delivery (Betancourt et al. 2016). Secondly, the ability to provide products that match the emerging trend in the marketplace, product support or after-sales service (Goffin 1998). Thirdly, another of support is seen in the existence of good inventory management to maintain stable product supply (Lee et al.2011) from manufacturer to channel of distribution or between members of the channel of distribution.

Based on the strength of our literature review, we propose market support advantage variable in our model as a series of superiorities designed and implemented by a firm or a manufacturer to support its channel of a distribution network. These advantages may take a form of resourcebased support, product-related support, promotion-related support, sales and distribution-related support and consumer's leverage-related support. Marketing support to distribution channel as a kind of service of principal or a parent firm to sellers or retail outlet is postulated as having a positive impact on the value of service perceived by customers and consumer and impacts the performance (Brady and Robertson 1999). Marketing support is believed to have a significant impact on a channel of distribution. Marketing support may take a form of push effect strategies such as increasing the efficiency of promotion investment of distribution channel by subsidizing the retailers' regular promotions such as a cooperative advertising program (Karray 2015). Therefore, the following two hypotheses are proposed.

H4: Entrepreneurial orientation positively influences Marketing support advantage.

H5: Marketing Support Advantage positively influences Pareto sales network asset.

\section{Research method}

\subsection{Sample and data collection}

To test our model, we include our sample of SME handicraft product industry from Yogyakarta, Solo, and Bandung in 
Indonesia. Those three cities are chosen because Bandung is already recognized as a creative city by UNESCO while Yogyakarta and Solo are also prepared to be creative cities based on their potential in craft and art design. Our study considers an SME creative firm is attractive for scientific research because the size of the business is relatively small regarding numbers of people involved in the business process and marketing process lead companies to choose a specific move for implementing their marketing strategy through cooperating with an external entity for spreading product and enhancing sales performance. Considering this type of firm is working with small numbers of staff mainly led by the owner-manager, the collection of data is done through a structured interview using survey questionnaire instrument. As the number of populations is unknown, our sampling method is convenience sampling a type of non-probability sampling method. In total, we got 158 SME handy-craft product industries for testing our model.

\subsection{Measurement of variables}

Entrepreneurial Orientation (EO): We adopt several concept and measures for developing our indicators and item to be questioned to our SMEs respondents. EO is reconstructed based on the item developed by Hughes and Morgan (2007) "We actively introduce improvements and innovations in our business" and adapted it to be an indicator as Pre-emptive moves, then itemized it in a sentence as "We actively introduce improvements and innovations in our business before our competitors do", "We always try to take the initiative in every situation (e.. against competitors, in projects and when working with others)", adopted it in developing indicator as proactive moves and transform to an item as "we always try to take the initiative for manoeuvring in the market place before competitors do". From the same source, we adapt these two items i.e. "The term 'risk taker is considered a positive attribute for people in our business", the item is considered a positive attribute for people in our business" and "People in our business are encouraged to take calculated risks with new ideas" to form our indicator as Risk-taking initiative by developing our item as "we always make an effort to catch every business opportunities before our competitor do by calculating risk carefully and prepare ways for managing every risk"

Pareto Sales Network Asset (PSNA): as described in our literature review section, PSNA is a group of strategic customers which are networked by a company that dominantly contribute to company's sales performance because of its ownership of the loyal customer, high sales turnover customer, and wide network customer. To measure this high impact sales network we based our measures on the concept of Anderson (2002) that for the marketer, treating customers as partners is important for getting a Pareto efficiency in business through mutually beneficial networking. Supported by the notion of greatest yield resources as studied by Craft and Leake (2002), we develop our indicators for PSNA as 1. Trusted, committed, and loyal distribution network member; 2. High-sales turnover network member; 3 . Wide network customer.

Marketing Support Advantage (MSA): Several sources on distribution channel support, direct support from the factory (Goffin 1998); and support activity (Lee et al. 2011) are adapted to form our indicator measurement as follows: 1. Superiority in product support to distribution channel; 2. Superiority in resource support to distribution channel; 3. Superiority in sales program support to the distribution channel.

Sales growth performance (SGP): Adapting the items used by Bental and Spiegel (1995), Green et al. (2012), and Kantur (2016), SGP is measured by 1 . Sales growth; 2 . Customer/buyer growth; 3 . Market coverage scope.

\section{Data analysis and findings}

\subsection{Data analysis}

Data were analyzed using the SEM IBM-AMOS 21 package for testing the fitness of the model and the relationship between variables of the model. Table 1 presents a list of measurement items with standardized estimates and a critical ratio for evaluating the construct validity of the concept used in this research, based on AMOS output of confirmatory factor analysis (Arbuckle 2016).

Scale, measurement, validity, and reliability of the variables are presented in Table 1.

The confirmatory factor analysis resulted in the loading factor for every constructs or variable in the model is above the minimum expected value of 0.50 with a critical ratio is bigger than 1.96 indicated that the magnitude of the contribution of each indicator to the constructed variables is accepted with a significance level lower than 0.05 . Construct validity is measured by AVE- average variance extracted with a minimum level of $\geq 0.50$. The analysis resulted in a level of accepted convergent validity, such as 0.719 for EO, 0.734 for marketing support advantage, 0.610 for Pareto sales network asset, 0.677 for service value advantage and 0.590 for sales growth performance. The AVE of the latent variables at the level of $\geq 0.50$ indicating an adequate and well correlation between indicators that well mirroring the latent variables, as suggested by Fornell and Larcker (1981) a value of 0.5 or higher indicates an adequate convergence and that the scale has higher distinct validity, therefore, the latent variables are valid for further analysis. All the construct variables have excellent construct reliability such as EO (0.884), marketing support advantage (0.892), Pareto sales network asset (0.726), and sales growth performance (0.808), all construct's reliability are above 0.70 indicating 
Table 1. Scale, measurement, validity, reliability

\begin{tabular}{|c|c|c|c|c|c|}
\hline SCALE'S INDICATORS & SOURCE & Std. estimate & Critical ratio & $\begin{array}{c}\text { Convergent } \\
\text { validity-AVE }\end{array}$ & $\begin{array}{l}\text { Construct } \\
\text { reliability }\end{array}$ \\
\hline \multicolumn{6}{|l|}{ CFA EXOGENEOUS CONSTRUCT: } \\
\hline Entrepreneurial orientation: & \multirow{4}{*}{$\begin{array}{l}\text { Hughes and } \\
\text { Morgan (2007) }\end{array}$} & & & 0.719 & 0.884 \\
\hline Preemptive move & & 0.864 & 11.539 & & \\
\hline Proactive initiative & & 0.894 & 11.544 & & \\
\hline Risk-taking initiative & & 0.781 & $11.544^{*}$ & & \\
\hline \multicolumn{6}{|l|}{ CFA ENDOGENEOUS CONSTRUCTS: } \\
\hline Marketing support advantage: & \multirow{4}{*}{$\begin{array}{l}\text { Goffin (1998), } \\
\text { Lee et al. (2011) }\end{array}$} & & & 0.734 & 0.892 \\
\hline Product support-based advantage & & 0.832 & 13.442 & & \\
\hline Resource support-based advantage & & 0.919 & 13.442 & & \\
\hline Sales support based advantage & & 0.816 & 11.904 & & \\
\hline Pareto sales network asset: & \multirow{4}{*}{$\begin{array}{l}\text { Anderson } \\
(2002), \text { Craft } \\
\text { and Leake } \\
(2002)\end{array}$} & & & 0.610 & 0.824 \\
\hline $\begin{array}{l}\text { Trusted, committed, and loyal sales } \\
\text { network member }\end{array}$ & & 0.772 & 9.597 & & \\
\hline High-sales turnover network member & & 0.836 & 10.252 & & \\
\hline Wide network customer & & 0.783 & $10.252^{*}$ & & \\
\hline Sales growth performance: & \multirow{4}{*}{$\begin{array}{l}\text { Bental and } \\
\text { Spiegel (1995), } \\
\text { Green et al. } \\
\text { (2012), Kantur } \\
(2016)\end{array}$} & & & 0.590 & 0.808 \\
\hline Sales growth & & 0.690 & 7.574 & & \\
\hline Customer growth & & 0.923 & 8.752 & & \\
\hline Market coverage & & 0.664 & $8.752^{*}$ & & \\
\hline
\end{tabular}

* These variables are estimated twice. First as a constrained variable, second as a not constrained variable for checking its critical ratio. Source: authors' data processing.

the good acceptance level of construct or composite reliability of the variables in the model (Bagozzi 1981, Farooq 2016).

In observing the quality of data for further analysis using the structural equation modeling technique, to fulfill the requirement of multivariate statistical procedures, data normality was observed. By the first run of the model, almost the entire variable used was indicating a non-normal distribution. Therefore, certain steps should be taken. Firstly, the stability and consistency of data provided by the respondents were re-evaluated. Respondents with extreme responses were eliminated from the data series. The second step was to test the normal distribution of our data, and as suggested by Tabachnick and Fidell (2012), data with moderate negative skewness should be transformed with the square root of $\mathrm{k}$ - $\mathrm{x}$ formula). The original data based was converted using Square root of (11-x) formula, resulting in a data series with a normal distribution pattern. This step provided a data profile that did not indicate the existence of a non-normality profile. This process is a generally accepted procedure, as data analysis in structural equation modeling does not use the raw data, but instead uses the covariance data as an input for further data processing.

Following our measurement model with the confirmatory factor analysis, a structural model analysis was conducted to test the proposed hypotheses. The result is presented in Figure 1.

\subsection{Hypothesis testing}

A goodness-of-fit of model analysis was confirmed by statistical measures of Chi-square 64.176 with a significance level of 0.086 indicating the acceptance of the model. The non-statistical measures such as GFI=0.936; AGFI =0.903; TLI $=0.983$; CFI $=0.987$, and the RMSEA level of 0.043 demonstrating the acceptance of model (Arbuckle 2016).

The structural coefficient of regression is presented in the following Table 2 .

The regression coefficient for $\mathrm{H} 1$ is $0.305, \mathrm{H} 2$ is 0793 , $\mathrm{H} 4$ is $0.414, \mathrm{H} 5$ is 0.5503 all are presented with a critical ratio or $\mathrm{t}$-value larger than 1.96 indicates the acceptance of the hypothesis.

\subsection{Mediating effect}

To test the mediation effect in the model, we adopt the mediating procedure of Baron and Kenny (1986), which to identify the mediation effect of a mediation variable is that 1 . There should be a significant regression coefficient of independent to dependent variable; 2. There should be a significant regression coefficient of 
the independent variable to mediation variable; 3 . There should be a regression coefficient of mediation variable to dependent variable; 4 . The significant regression coefficient of independent to a dependent variable should be significantly reduced or become insignificant when the mediation variable is inserted in the model. To do so, we rerun the model with four steps as presented in the bottom of Table 2. When the Pareto sales network asset is inserted in the model, the effect of EO on sales growth performance is changing lower (0.503 decreases to 0.141 ) and insignificant. Our result indicates the importance of the Pareto sales network asset as a full mediation for the relationship between EO and sales growth performance.

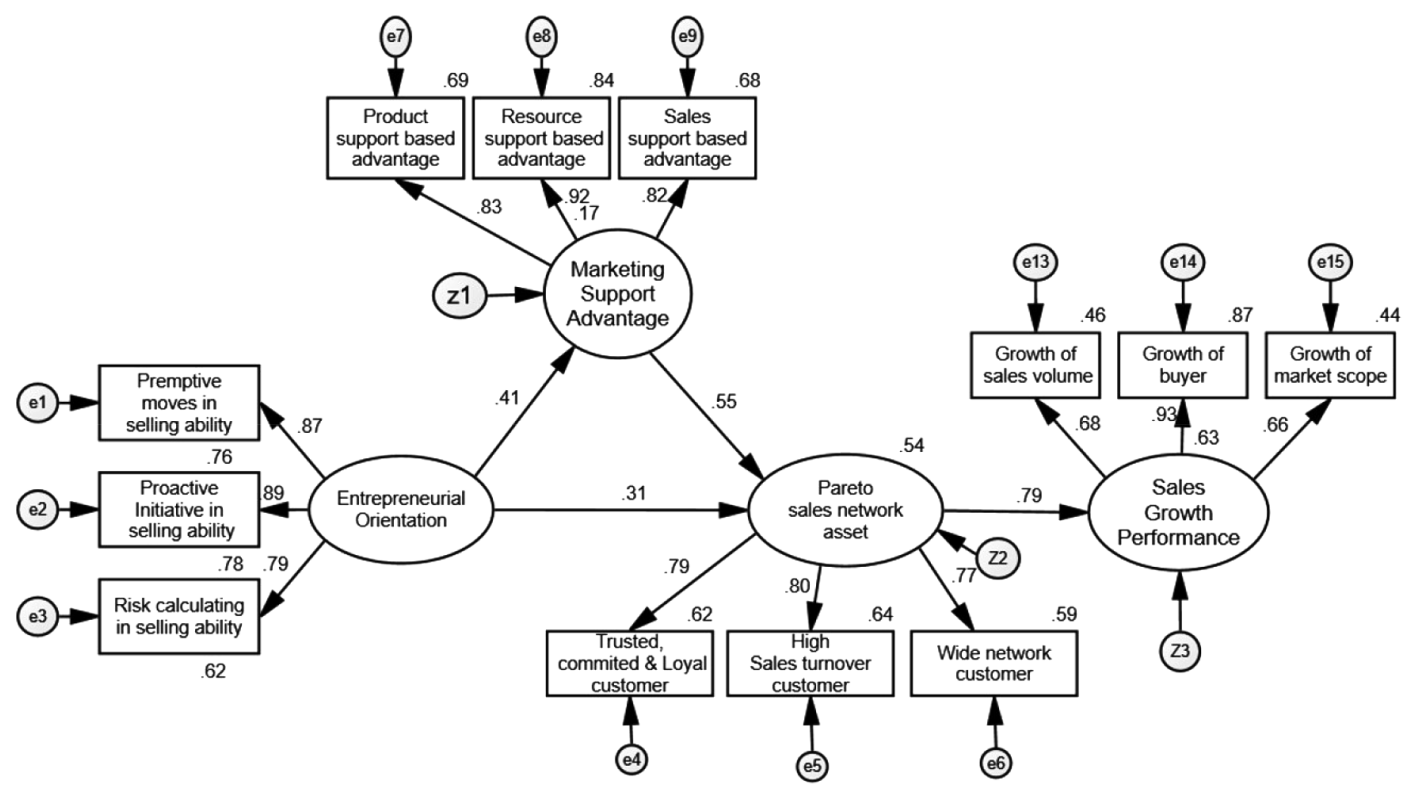

Model testing: Chi-square $=64.176 ;$ Significance $=.086 ; \mathrm{GFI}=.938 ; \mathrm{AGFI}=.903 ; \mathrm{TLI}=.983 ; \mathrm{CFI}=.987 ; \mathrm{RMSEA}=.043$

Figure 1. Empirical Research model testing

Table 2. The structural coefficient of regression

\begin{tabular}{|c|c|c|c|c|c|c|}
\hline HYPOTHESIS & Std. estimate & Estimate & Std. error & Critical Ratio & Significance & Conclusion \\
\hline $\begin{array}{l}\text { H1: Entrepreneurial orientation } \\
\rightarrow \text { Pareto sales network asset }\end{array}$ & .305 & .299 & .081 & 3.698 & $* * *$ & Supported \\
\hline $\begin{array}{l}\text { H2: Pareto sales network asset } \rightarrow \\
\text { Sales growth performance }\end{array}$ & .793 & .646 & .095 & 6.826 & $* * *$ & Supported \\
\hline $\begin{array}{l}\text { H4: Entrepreneurial orientation } \\
\rightarrow \text { Marketing support advantage }\end{array}$ & .414 & .445 & .096 & 4.622 & $* * *$ & Supported \\
\hline $\begin{array}{l}\text { H5: Marketing support advantage } \\
\rightarrow \text { Pareto sales network asset }\end{array}$ & .550 & .500 & .082 & 6.124 & $* * *$ & Supported \\
\hline $\begin{array}{l}\text { H3: Pareto sales network asset me- } \\
\text { diates entrepreneurial orientation } \\
\text { to sales growth performance }\end{array}$ & \multicolumn{5}{|c|}{ Full mediation is confirmed } & \\
\hline Step 1: EO $\rightarrow$ SGP & .503 & .422 & .084 & 5.002 & $* * *$ & Supported \\
\hline Step 2: EO $\rightarrow$ PSNA & .501 & .500 & .094 & 5.296 & $* * *$ & Supported \\
\hline Step 3: PSNA $\rightarrow$ SGP & .751 & .605 & .092 & 6.575 & $* * *$ & Supported \\
\hline \multirow[t]{2}{*}{ Step 4: EO $\rightarrow$ SGP } & .141 & .116 & .068 & 1.673 & 0.09 & $\begin{array}{l}\text { Not supported } \\
\text { at } 0.05\end{array}$ \\
\hline & \multicolumn{5}{|c|}{$\begin{array}{l}\mathrm{EO} \rightarrow \mathrm{SGP} \text { becomes insignificant, and the magnitude of effect reduces when the } \\
\text { mediation variable is inserted in the model }\end{array}$} & \\
\hline
\end{tabular}




\section{Research contribution and direction for future research}

\subsection{Research contribution}

The current study brings our main question of what process should be taken into a strategic action for transforming the input-EO for effectively enhancing performance. Based on the acceptance of the hypotheses and the magnitude of the relationship between variables, several findings are presented in the following passage.

Transplanting the Castells' networked power (Castells 2011) into SMEs marketing study, this study demonstrates a process-angle of EO concept where an entrepreneurial oriented firm internally builds its networking power - power for attracting external resource for joining a network in term of its innovativeness and pro-activeness in doing business. EO firm that success in accessing the Pareto sales network which by nature is outside of the firm will get the networked power. Having, maintaining and using the networked power from a Pareto sales network asset will be a key asset for enhancing sales growth performance.

This finding on networked power in a Pareto sales network asset extend the study of Homburg et al. (2009) a company hold a strong basis for enhancing performance through a Pareto sales network asset. The more the effectiveness of utilizing the Pareto sales network asset, the higher the level of sales growth performance could be harvested. The logic behind this notion is that a company with strong EO will have the capability to gain access to the Pareto sales network that forms a type of networked power (Castells 2011) for enhancing sales growth performance. If companies can maintain and cultivate their EO, they will possess a high capability to access key distribution companies in the marketplace, which in turn will secure and enhance sales growth performance. The acceptance of hypotheses related to this pathway supports the study by Tsybina and Rebiazina (2013), who demonstrated that interconnectedness and a good relationship with a customer enhance the quality of the customer portfolio. An entrepreneurial company that is seen as a company with greater pre-emptive moves in the marketplace, a more significant pro-active initiative in exploring and exploiting market opportunities with a very calculated risk-taking strategy, will be perceived by distribution companies as more attractive to cooperate. This notion does support the study by Lavie (2007), i.e., that a business networking value creation or value co-creation process (Haas et al. 2012) is a strategic anchor in increasing networking for gaining benefit as a relational rent, created through co-marketing network resources alongside human network resources, and network prominence. If this condition occurs, a company becomes more adaptive in securing and enhancing sales growth performance. The acceptance of the hypotheses for this pathway does support the study of
Sullivan, Peterson, and Krishnan (2012), i.e., that company tied together in a network, particularly a network with distribution companies, will create and secure a solid foundation for sales and marketing performance.

The importance of marketing support advantage in cultivating the Pareto Sales Network Asset is also recognized in this study which strengthen the study of Betancourt et al. (2016) that whether selling through online or offline distribution system, company should consider the maximum level of distribution service in order to work effectively and efficiently in the competitive marketplace. The acceptance of marketing support advantage hypothesis is strengthening the study of Karray (2015) demonstrated the importance of joint promotion as a type of marketing support that theorized as having an impact on the effectiveness of supply-side management and especially supply chain for supporting marketing performance.

As the primary anchor of our research is in the introduction of Pareto sales network asset, the acceptance of the related hypothesis strengthens a notion that the advantages of being EO company should be utilized for strengthening the basis for access to the Pareto sales network asset. Managers and their subordinates should regularly consider how to cooperate, maintain and co-value creation with the trusted, committed, and loyal customer, the high sales turnovercustomer, and wide network customer in company marketing decision as a strategic resource for enhancing sales growth. As a Pareto sales network asset is understood as one of the vital few distribution partners that strategically determine company's marketing performance, company that possesses or cooperates with this very strategic asset would have superior sales growth performance if the Pareto sales network asset is managed effectively.

This study focuses on the importance of the Pareto sales network asset as a strategic asset for SMEs in enhancing its marketing performance. As demonstrated by the regression weight in the analyzed model, networking with high sales turnover customer-that more experiencing in maneuvering in the very dynamic market environment will be a more powerful engine for growth for a small company that mainly focus on production that exists in a more stable and controllable environment. The trusted and the committed customer is a stabilizer for encountering the dynamics in the marketplace. Therefore, SMEs which are networking with this type of customer will benefit from protecting against the dynamic competition in the marketplace. A customer with wide selling network is recognized as leverage for the fast spreading of products into the wider market area. Networking with this type of customer will be a strategic vehicle for pre-emptively making a strong position in the marketplace. For an SME, making efforts to network with the Pareto customer will be a pivotal aspect of developing and harvesting from the Pareto sales network asset. 


\subsection{Future research}

Study on the Pareto sales network asset is a new initiative to explain the way an entrepreneurial oriented SME enhance sales performance. This study was well-prepared and scientifically conducted, several limitations should be addressed. First, the ontology of the Pareto sales network asset as a novelty of this study has been clearly defined in the essential meaning of the concept, effort to construct the dimensions of the concept is open for further research and retested in the same industry and across industries. Second, as a preliminary study, the model was tested in only one industry. Consequently, the power of generalization of the Pareto sales network asset is still limited. Therefore replications of this study across firms and industries are encouraged to increase the power of generalization of this concept.

\section{Acknowledgment}

Special acknowledgment is for our respondents-the ownermanagers in the city of Solo, Yogyakarta, and Bandung for their cooperation in this research.

\section{References}

Akgün AE, Keskin H, Byrne JC (2014) Complex adaptive systems theory and firm product innovativeness. Journal of Engineering and Technology Management 31: 21-42. https://doi. org/10.1016/j.jengtecman.2013.09.003

Al-Dhaafri HS, Al-Swidi A (2016) The impact of total quality management and entrepreneurial orientation on organizational performance. International Journal of Quality \& Reliability Management 33 (5): 597-614. https://doi.org/10.1108/ IJQRM-03-2014-0034

Al-Dhaafri HS, Al-Swidi AK, Yusoff RZB (2016) The mediating role of total quality management between the entrepreneurial orientation and the organizational performance. The TQM Journal 28 (1): 89-111. https://doi.org/10.1108/TQM-032014-0033

Anderson ET (2002) Sharing the wealth: when should firms treat customers as partners?. Management Science 48 (8): 955-971. https://doi.org/10.1287/mnsc.48.8.955.170

Arbuckle JL (2016) IBM $^{\circledast}$ SPSS $^{\circledast}$ Amos $^{\text {Tn }}$ User’s Guide.

Avlonitis GJ, Salavou HE (2007) Entrepreneurial orientation of SMEs, product innovativeness, and performance. Journal of Business Research 60 (5): 566-575. https://doi.org/10.1016/j. jbusres.2007.01.001

Bagozzi RP (1981) Evaluating structural equation models with unobservable variables and measurement error: a comment. JMR, Journal of Marketing Research 18 (3): 375. https://doi. org/10.2307/3150979

Baker WE, Sinkula JM (2009) The complementary effects of market orientation and entrepreneurial orientation on profitability in small businesses. Journal of Small Business Management 47 (4): 443-464.

Baron RM, Kenny DA (1986) The moderator-mediator variable distinction in social psychological research: conceptual, strategic, and statistical considerations. Journal of Personality and Social Psychology 51 (6). https://doi.org/10.1037/00223514.51.6.1173

Bayhan M, Serinkan C, Arat G (2013) Evaluation of staff attitudes related to innovation management: an empirical study in a service sector in Turkey. Procedia - Social and Behavioral Sciences 89: 323-327. https://doi.org/10.1016/j. sbspro.2013.08.854

Bental B, Spiegel M (1995) Network competition, product quality, and market coverage in the presence of network externalities. The Journal of Industrial Economics 43 (3): 197-208. https:// doi.org/10.2307/2950481

Best RJ (2009) Market-based management: strategies for growing customer value and profitability (5th ed.) Upper Saddle River, New Jersey: Pearson Education, Inc.

Betancourt RR, Chocarro R, Cortiñas M, Elorz M, Mugica JM (2016) Channel choice in the 21st century: the hidden role of distribution services. Journal of Interactive Marketing 33: 1-12. https://doi.org/10.1016/j.intmar.2015.09.002

Brady MK, Robertson CJ (1999) An exploratory study of service value in the USA and Ecuador. International Journal of Service Industry Management 10 (5): 469-486. https://doi. org/10.1108/09564239910289003

Castells M (2011) A Network Theory of Power. International Journal of Communication 5: 15.

Covin JG, Slevin DP (1989) Strategic Management Of Small Firms In Hostile And Benign E. Strategic Management Journal 10 (1): 75. https://doi.org/10.1002/smj.4250100107

Craft RC, Leake C (2002) The Pareto principle in organizational decision making. Management Decision 40 (7/8): 729-733. https://doi.org/10.1108/00251740210437699

Davis JL, Bell RG, Payne GT, Kresier PM (2010) Entrepreneurial orientation and firm performance: the moderating role of managerial power. American Journal of Business 25 (2): 41 54. https://doi.org/10.1108/19355181201000009

Deutscher F, Zapkau FB, Schwens C, Baum M, Kabst R (2016) Strategic orientations and performance: a configurational perspective. Journal of Business Research 69 (2): 849-861. https://doi.org/10.1016/j.jbusres.2015.07.005

Emslie L, Bent R (2007) Public sector business support providers: marketing business support to the ethnic business sector. Marketing Intelligence \& Planning 25 (5): 460-482. https:// doi.org/10.1108/02634500710774941

Engel Y, Kaandorp M, Elfring T (2017) Toward a dynamic process model of entrepreneurial networking under uncertainty. Journal of Business Venturing 32 (1): 35-51. https://doi. org/10.1016/j.jbusvent.2016.10.001

Fabella RV (2000) Generalized sharing, membership size and pareto efficiency in teams. Theory and Decision 48 (1): 47-60. https://doi.org/10.1023/A:1005236224786

Farooq R (2016) Role of structural equation modeling in scale development. Journal of Advances in Management Research 13 (1): 75-91. https://doi.org/10.1108/JAMR-05-2015-0037

Fornell C, Larcker DF (1981) Structural equation models with unobservable variables and measurement error: algebra and statistics. JMR, Journal of Marketing Research 18 (3): 382. https://doi.org/10.2307/3150980 
Frank H, Kessler A, Fink M (2010) Entrepreneurial orientation and business performance - a replication study. Schmalenbach Business Review 62 (2): 175-198. https://doi.org/10.1007/BF03396804

Goffin K (1998) Customer support distribution channels: five exploratory case studies. The Cranfield School of Management Working Papers Series, (SWP 20/98). Cranfield Bedfordshire.

Green KW, Whitten D, Inman RA (2012) Aligning marketing strategies throughout the supply chain to enhance performance. Industrial Marketing Management 41 (6): 1008-1018. https:// doi.org/10.1016/j.indmarman.2012.02.003

Haas A, Snehota I, Corsaro D (2012) Creating value in business relationships: the role of sales. Industrial Marketing Management 41 (1): 94-105. https://doi.org/10.1016/j.indmarman.2011.11.004

Homburg C, Steiner VV, Totzek D (2009) Managing dynamics in a customer portfolio. Journal of Marketing 73: 70-89. https:// doi.org/10.1509/jmkg.73.5.70

Home N (2011) Entrepreneurial orientation of grocery retailers in Finland. Journal of Retailing and Consumer Services 18 (4): 293-301. https://doi.org/10.1016/j.jretconser.2011.02.003

Hughes M, Morgan RE (2007) Deconstructing the relationship between entrepreneurial orientation and business performance at the embryonic stage of firm growth. Industrial Marketing Management 36 (5): 651-661. https://doi.org/10.1016/j. indmarman.2006.04.003

Iyer AV, Bergen ME (1997) Quick response in manufacturer-retailer channels. Management Science 43 (4): 559-570. https:// doi.org/10.1287/mnsc.43.4.559

Kantur D (2016) Strategic entrepreneurship: mediating the entrepreneurial orientation-performance link. Management Decision 54 (1): 24-43. https://doi.org/10.1108/MD-11-2014-0660

Karray S (2015) Cooperative promotions in the distribution channel. Omega 51: 49-58. https://doi.org/10.1016/j.omega.2014.07.009

Lavie D (2007) Alliance portfolios and firm performance: a study of value creation and appropriation in the U.S. software industry. Strategic Management Journal 28 (12): 1187-1212. https://doi.org/10.1002/smj.637

Lee TR, Hsu Y, Lin C-J, Phusavat K, Sinnarong N (2011) Vertical Integration in the Taiwan Aquaculture Industry. Managing Global Transitions 11 (1): 61-78, 17.

Li Y-H, Huang J-W, Tsai M-T (2009) Entrepreneurial orientation and firm performance: the role of knowledge creation process. Industrial Marketing Management 38 (4): 440-449. https:// doi.org/10.1016/j.indmarman.2008.02.004

Liao L-K, Lin Y-M, Lin T-W (2016) Non-financial performance in product market and capital expenditure. Journal of Business Research 69 (6): 2151-2159. https://doi.org/10.1016/j. jbusres.2015.12.023

Lumpkin GT, Dess GG (1996) Clarifying the entrepreneurial orientation construct and linking it to performance. Academy of Management Review 21 (1): 135-172. https://doi. org/10.5465/amr.1996.9602161568

Lumpkin GT, Dess GG (2001) Linking two dimensions of entrepreneurial orientation to firm performance: The moderating role of environment and industry life cycle. Journal of Business Venture 16: 429-451. https://doi.org/10.1016/ S0883-9026(00)00048-3
Madsen EL (2007) The significance of sustained entrepreneurial orientation on performance of firms - a longitudinal analysis. Entrepreneurship \& Regional Development 19 (2): 185-204. https://doi.org/10.1080/08985620601136812

Merlo O, Auh S (2009) The effects of entrepreneurial orientation, market orientation, and marketing subunit influence on firm performance. Marketing Letters 20 (3): 295-311. https://doi. org/10.1007/s11002-009-9072-7

Miller D (1983) The correlates of entrepreneurship in three types of firms. Management Science 29 (7): 770-791. https://doi. org/10.1287/mnsc.29.7.770

Miller D, Friesen PH (1982) Innovation in conservative and entrepreneurial firms: two models of strategic momentum. Strategic Management Journal (pre-1986) 3 (1): 1.

Morgan NA (2012) Marketing and business performance. Journal of the Academy of Marketing Science 40 (1): 102-119. https:// doi.org/10.1007/s11747-011-0279-9

Morgan NA, Clark BH, Gooner R (2002) Marketing productivity, marketing audits, and systems for marketing performance assessment Integrating multiple perspectives. Journal of Business Research 55: 363-375. https://doi.org/10.1016/ S0148-2963(00)00162-4

Morgan T, Anokhin S, Wincent J (2016) Entrepreneurial orientation, firm market power and opportunism in networks. Journal of Business \& Industrial Marketing 31 (1): 99-111. https://doi.org/10.1108/JBIM-03-2014-0063

Morris MH, Schindehutte M, LaForge RW (2002) Entrepreneurial marketing: a construct for integrating emerging entrepreneurship and marketing perspectives. Journal of Marketing Theory and Practice 10 (4): 1-19. https://doi.org/10.1080/10 696679.2002.11501922

Naudé P, Zaefarian G, Najafi Tavani Z, Neghabi S, Zaefarian R (2014) The influence of network effects on SME performance. Industrial Marketing Management 43 (4): 630-641. https:// doi.org/10.1016/j.indmarman.2014.02.004

Pearce II JA, Fritz DA, Davis PS (2010) Entrepreneurial orientation and the performance of religious congregations as predicted by Rational Choice Theory. Entrepreneurship Theory and Practice 34 (1): 219-248. https://doi.org/10.1111/j.15406520.2009.00315.x

Raassens N, Wuyts S, Geyskens I (2014) The performance implications of outsourcing customer support to service providers in emerging versus established economies. International Journal of Research in Marketing 31 (3): 280-292. https:// doi.org/10.1016/j.ijresmar.2014.01.002

Ramachandran K, Ramnarayan S (1993) Entrepreneurial orientation and networking: some Indian Evidence. Journal of Business Venturing 8: 513-524. https://doi.org/10.1016/08839026(93)90036-5

Rauch A, Wiklund J, Lumpkin GT, Frese M (2009) Entrepreneurial orientation and business performance: an assessment of past research and suggestions for the future. Entrepreneurship Theory and Practice 33 (3): 761-787. https://doi. org/10.1111/j.1540-6520.2009.00308.x

Rust RT, Ambler T, Carpenter GS, Kumar V, Srivastava RK (2004) Measuring marketing productivity: current knowledge and future directions. Journal of Marketing 68: 76-89. https://doi. org/10.1509/jmkg.68.4.76.42721 
Sanders RE (1987) The Pareto Principle: its use and abuse. The Journal of Services Marketing 1 (2): 37. https://doi. org/10.1108/eb024706

Semrau T, Ambos T, Sascha K (2016) Entrepreneurial orientation and SME performance across societal cultures: an international study. Journal of Business Research 69 (5): 1928-1932. https://doi.org/10.1016/j.jbusres.2015.10.082

Shane S, Locke EA, Collins CJ (2003) Entrepreneurial motivation. Human Resource Management Review 13 (2): 257-279. https://doi.org/10.1016/S1053-4822(03)00017-2

Soininen J, Martikainen M, Puumalainen K, Kyläheiko K (2012) Entrepreneurial orientation: growth and profitability of Finnish small- and medium-sized enterprises. International Journal of Production Economics 140 (2): 614-621. https:// doi.org/10.1016/j.ijpe.2011.05.029

Sullivan UY, Peterson RM, Krishnan V (2012) Value creation and firm sales performance: the mediating roles of strategic account management and relationship perception. Industrial Marketing Management 41 (1): 166-173. https://doi. org/10.1016/j.indmarman.2011.11.019

Tabachnick BG, Fidell LS (2012) Using multivariate statistics (6 ed) New York: Pearson Publisher.

Tang J, Tang Z, Zhang Y, Li Q (2007) The impact of entrepreneurial orientation and ownership type on firm performance in the emerging region of China. Journal of Developmental Entrepreneurship 12 (4): 383-397. https://doi.org/10.1142/ S1084946707000733
Tsybina E, Rebiazina V (2013) Managing portfolios of interconnected customers: evidence from Russian B2B market. Journal of Business \& Industrial Marketing 28 (3): 229-239. https:// doi.org/10.1108/08858621311302886

Walter A, Auer M, Ritter T (2006) The impact of network capabilities and entrepreneurial orientation on university spin-off performance. Journal of Business Venturing 21 (4): 541-567. https://doi.org/10.1016/j.jbusvent.2005.02.005

Wang G, Dou W, Zhu W, Zhou N (2015) The effects of firm capabilities on external collaboration and performance: the moderating role of market turbulence. Journal of Business Research 68 (9): 1928-1936. https://doi.org/10.1016/j. jbusres.2015.01.002

Wiklund J (1999) The sustainability of the entrepreneurial orientation - performance relationship. Entrepreneurships Theory and Practice, Fall, 37-48. https://doi. org/10.1177/104225879902400103

Wolff JA, Pett TL, Ring JK (2015) Small firm growth as a function of both learning orientation and entrepreneurial orientation: an empirical analysis. International Journal of Entrepreneurial Behavior \& Research 21 (5): 709-730. https://doi.org/10.1108/ IJEBR-12-2014-0221

York JG, Venkataraman S (2010) The entrepreneur-environment nexus: uncertainty, innovation, and allocation. Journal of Business Venturing 25 (5): 449-463. https://doi.org/10.1016/j. jbusvent.2009.07.007 